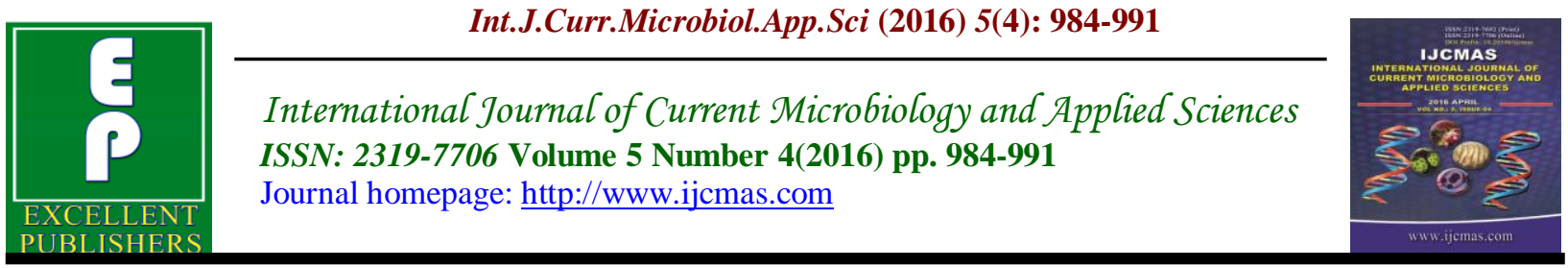

Original Research Article

http://dx.doi.org/10.20546/ijcmas.2016.504.112

\title{
Effect of the Spreading of Sludge on the Chemical Quality of Clay Soil; Casablanca-Morocco
}

\author{
Najib Saber $^{1}$, Hajar Mohcine ${ }^{1 *}$ and Imane Benazzouz ${ }^{2}$ \\ ${ }^{1}$ University Hassan II-Casablanca/Faculty of Ben M'Sik Sciences/Laboratory of Applied \\ Geology, Geomatics and Environment, Morocco \\ ${ }^{2}$ Faculty of Medicine, Biochemistry Laboratory, Université Hassan II Casablanca, Morocco \\ *Corresponding author
}

\section{A B S T R A C T}

\section{Keywords}

Sludge,

Compost,

Soil Quality,

Chemical

Indicators.

Article Info

Accepted:

10 March 2016

Available Online:

10 April 2016
In order to valorize the sludge from refining sugar as compost, we are interested to studying the effect of the sludge on the chemical quality of an agricultural soil in the area of Casablanca. The device split plot with three repetitions was used in two crops (wheat and Lucerne). The valorization of sludge is conducted by testing three progressive doses of $50 \mathrm{~g}, 100 \mathrm{~g}$ and $200 \mathrm{~g}$ of sludge for both cultures. Chemical indicators assessed soil quality namely: organic matter $(\mathrm{OM}), \mathrm{pH}$, calcium carbonate and salinity. Analyzes of soil samples taken at different stages of the life cycle have shown that the contribution of sludge contributes to the enrichment of organic matter and calcium carbonate and an increase in the salinity. This enrichment is higher in cultivated soils compared to uncultivated soils. In contrast, the $\mathrm{pH}$ values do not seem to be affected by the addition of sludge, but they record different effects depending on the two cultures.

\section{Introduction}

Human activities generate various wastes in increasingly high quantity: industrial waste, household waste, urban wastewater. Management of these wastes poses a huge problem. In order to limit their environmental impact, their treatment is indispensable and, possibly, a recycling of certain amount is essential.

Sludge wastes deriving from the refinery of sugar were considered, since a pretty while, as wastes capable of influencing terrestrial and aquatic ecosystems.
However, apart from their origin, the high levels of organic matter, total nitrogen, phosphorous and trace elements of sludge led to, some twenty years ago, their use in agricultural environments.

This type of amendment adds value and recycles soil originated nutrients (Driver et al., 1999), increases and maintains soil productivity in the short and long term (Brossard et al., 1991). 
The incorporation of these wastes can contribute to the improvement of soil physical (structure, water retention, wett ability), chemical (pH, CEC) and biological (nitrogen cycle, microbial biomass) properties. These effects are often attributed to usual increase in the content of soils' stable organic matter (Remy and MarinLafleche (1976); Khaleel et al. (1981); Clapp et al. (1986); Lineres et al. (1985); (1988).

In this present work/review, we will try to determine the influence (effects) of sludge on the chemical properties of agricultural soils.

Thus, the main objective of this work is to monitor the evolution of the chemical quality of a clay soil through the following indicators: organic matter content, $\mathrm{pH}$, calcium carbonates and salinity.

The monitoring will be done, in the laboratory, by the use of a pot-form device with three repetitions and will be applied to two different crops (wheat and Lucerne/alfalfa).

\section{Materials and Methods}

\section{Chemical Analyses}

The organic matter analysis used here was performed according to the Walkley and Black (1934) method. The $\mathrm{pH}$ was measured using the electrometric method with a soil/water ratio of 0.5 (Mc lead 1983).For the determination of calcium carbonate, the Bernard: Chamley (1966) method was retained while the electrical conductivity was measured using the Rhoades (1976) method.

\section{The Experimental Device}

A split plot device with three repetitions was retained for this experiment. $1.5 \mathrm{~kg}$ of soil was placed in each pot (30 pots in total) with the pots being divided in three groups/sets:

* 6 pots were not cultivated

* 12 pots containing wheat crop

* 12 pots containing Lucerne (alfalfa) crop

The distribution of these groups was based on a contribution of different muds:

E1: control soil(sample) without crop, without any mud;

E2: cultivated soil without any mud;

E3: cultivated soil containing $50 \mathrm{~g}$ of mud;

E4: cultivated soil containing $100 \mathrm{~g}$ of mud;

E5: cultivated soil containing $200 \mathrm{~g}$ of mud.

The device was continually irrigated during the test.

\section{Results and Discussion}

\section{Soil Characterization}

The soil comes from the Grand Casablanca region. It is a clay soil with the following characteristics as shown in Table 1 . The $\mathrm{pH}$ is relatively high with an average organic matter content $(1.3 \%)$ while the electrical conductivity is in the order of $1.3 \mathrm{~ms}$.

\section{Characteristics of the Mud}

The mud used during this test comes from the Consumar sugar industry in Casablanca, which transforms the raw sugar into refined sugar having different forms: loaf, ingots and cubes. The activity that generates the most waste in the Consumar production is found at the filtration unit. 
Indeed, during the processing of the raw material, only a fraction is recovered after filtration; this recovered fraction subsequently undergoes the necessary processing in order to obtain mud. The other fractions, in the order of 60t/jour (R.A. 2009), are discarded.

Some analytical results are shown in Tables 2 and 3 below. These results, however, present the characteristics as well as the chemical composition of the mud after drying, sieving and grinding. The $\mathrm{pH}$ is alkaline while the organic matter content is high and goes as far as $5.17 \%$.

\section{Effects of Mud Input on the Chemical Properties of Soils (Wheat Crop)}

\section{Organic Matter}

The input of increased dose of mud leads to the enrichment of a soil organic matter, a fact that is consistent with the works of Juste and Catroux (1980). A comparison of the samples of organic matter content as they are received from different doses of mud shows that: the organic matter contents increase by $1.84 \%$ and $2.56 \%$ respectively compared to the control soil(E1) in the $1^{\text {st }}$ and $2^{\text {nd }}$ samples (fig.1).On the other hand, for the $3^{\text {rd }}$ sample, the organic matter content decreases to $1.38 \%$ compared to $\mathrm{E} 1$; the percentage of organic matter in the soil dosed with $200 \mathrm{~g}$ of mud (D3) is higher than the one dosed with $50 \mathrm{~g}$ of mud (D1). Sammer (1977) attributed this increase to the presence of organic compounds in the sludge that promotes organic carbon enrichment.

\section{pH}

The evolution of the $\mathrm{pH}$ due to the input of different doses of sludge shows that the input of the latter doesn't significantly modify the $\mathrm{pH}$ of soils in which the doses were spread as compared to the control soil; evidence clearly seen throughout the three samples (fig.1).

Whereas the $\mathrm{pH}$ values in the $1^{\text {st }}$ and $2^{\text {nd }}$ samples are noticeably comparable, we record a slight decrease in the $3^{\text {rd }}$ sample. These results are not consistent with those discovered by King and Morris (1992). However, $\mathrm{pH}$ variations determine certain soil properties such as microbial activities, nutrients availability, and in particular, the mobility of trace elements.

\section{Calcium Carbonates}

Figure 1 shows that the mud addition causes a highly significant increase in the rate of calcium carbonate, which reaches $37 \%$ as compared to $9 \%$ in $\mathrm{E} 1$; this richness is attributed to the richness of mud containing high lime content. Indeed, the higher the dose used, the more important the increase; a statistic that can be remarked in all the samples. The $3^{\text {rd }}$ sample recorded the least calcium carbonate content when compared to the other samples. This decrease in the $3^{\text {rd }}$ sample can be attributed to the effect of dissolution due to irrigation.

\section{Salinity}

It is known that the addition of mud can cause a positive effect in improving the salinity of agricultural soils Mariscot (1986). A statistic that straightly concords with the results obtained during our test: the input of $200 \mathrm{~g}$ of mud doesn't significantly modify the salinity of the soil compared to the control soil, while it decreases in the other 3 samples that contain $100 \mathrm{~g}$.

However, the $100 \mathrm{~g}$ and $50 \mathrm{~g}$ doses led to an increase in the concentration of mineral salts in all of the samples. It seems that the application of mud at moderate level is greater than that applied at higher level (Fig. $1)$. 


\section{Effects of Mud Input on the Chemical Properties of Soils (Lucerne Crop)}

\section{Organic Matter}

When compared to the soil's initial composition, mud amendments lead to an increase in the rate of organic matter content. Benmouffok et al., (2005); Gomez et al., (1984) proved through their numerous works that organic matter content increases in soils treated with mud. Indeed, the control soil presents the lowest values as compared to the dosed soils.

The dosed soils present very high organic matter content; especially those with the $200 \mathrm{~g}$ of mud dose and respectively present the following values: $2.75 \%, 3.08 \%$ and $3.6 \%$ (fig. 2 ).

It's only in the $3^{\text {rd }}$ sample that we can clearly see the evolution of the percentage of organic matter in terms of mud input and which began at $1.37 \%$ (for the control soil) to subsequently reach $3.6 \%$ (for the soil dosed with $200 \mathrm{~g}$ of mud).

\section{pH}

The $\mathrm{pH}$ measured from the $1^{\text {st }}$ and $3^{\text {rd }}$ samples record an initial decrease compared to the control soil followed by an increase (fig.2). The $\mathrm{pH}$ of the soils dosed with $200 \mathrm{~g}$ of mud tends to increase even after 21 days of their spreading.

As for the $2^{\text {nd }}$ sample, the input of mud didn't increase the soil $\mathrm{pH}$ which was already $7.3 \%$.Generally, the mud input didn't mark a great effect on the soil's $\mathrm{pH}$.

\section{Calcium Carbonates}

The results indicate that the addition of mud causes an increase in the content of calcium carbonates when compared to the control soil in all three samples. The maximum values recorded by mud spreading are $22 \%$, $17.1 \%$ and $21.4 \%$ for the first, second and third samples respectively while those of the control soils do not exceed $12 \%, 9.5 \%$ and 7.1\%.Indeed, the rate of $\mathrm{CaCO} 3$ increases successively with increasing dose of mud compared to the control soil.

\section{Salinity}

Mud spreading contributes to the improvement of soil salinity, this relates to increasing doses, because we successively move from 1600, 2015 and $1185 \mathrm{mg} / \mathrm{l}$ for the first dose (50g) to 1635, 2425 and 1205 $\mathrm{mg} / \mathrm{l}$ for the third dose $(200 \mathrm{~g})$; a fact that concords in all of the samples (fig. 2).

\section{The Effects of Crop Type on the Soil's Chemical Properties (fig.3)}

\section{Organic Matter}

The soils that are cultivated and dosed with mud register higher organic matter content than that of uncultivated soil. Indeed, sludge gradually releases and makes them available to the plant throughout its cycle (Jamil et al., 2006; Pescod, 1992; Barbartik et al., 1985).

For samples E2 and E3, the organic matter contents are similar for each crop (wheat and Lucerne); however, the values recorded by Lucerne are higher than those recorded by wheat for sample E3 and E4. 
Table.1 Characteristics of the Soil

\begin{tabular}{lc}
\hline \multicolumn{1}{c}{ Soil characteristics } & Results \\
\hline pH (water) & 8,08 \\
M.O $(\%)$ & 1,37 \\
$\mathbf{C}(\%)$ & 0,80 \\
$\mathbf{C a C O}_{3}(\%)$ & 11 \\
C.E (ms) & 1,35 \\
Concentration in mineral salt (mg/l) & 675 \\
\hline
\end{tabular}

Table. 2 Characteristics of the Mud

\begin{tabular}{lc}
\hline \multicolumn{1}{c}{ Mud characteristics } & Results \\
\hline pH (water) & 8,29 \\
M.O (\%) & 5,17 \\
C (\%) & 3 \\
CaCO $_{3}(\%)$ & 84 \\
C.E (ms) & 0,79 \\
Concentration in mineral salt (mg/l) & 395 \\
\hline
\end{tabular}

Table.3 Chemical Analyzes of the Mud using X-ray Fluorescence

\begin{tabular}{cc}
\hline Compound Name & \% of concentration \\
\hline $\mathbf{C a O}$ & 49,3 \\
\hline $\mathbf{S O} \mathbf{O}_{3}$ & 1,82 \\
$\mathbf{M g O}$ & 1,35 \\
\hline $\mathrm{SiO}_{\mathbf{2}}$ & 1,28 \\
\hline $\mathbf{A l}_{\mathbf{2}} \mathbf{O}_{\mathbf{3}}$ & 0,503 \\
\hline $\mathbf{P}_{\mathbf{2}} \mathbf{O}_{\mathbf{5}}$ & 0,239 \\
\hline $\mathbf{F e}_{\mathbf{2}} \mathbf{O}_{\mathbf{3}}$ & 0,225 \\
\hline $\mathbf{N a}_{\mathbf{2}} \mathbf{O}$ & 0,173 \\
\hline $\mathbf{C l}$ & 0,0593 \\
\hline $\mathbf{K} \mathbf{O}$ & 0,0224 \\
\hline $\mathbf{S r O}$ & 0,0206 \\
\hline $\mathbf{Z n O}$ & 0,0131 \\
\hline
\end{tabular}

Fig.1 Effects of Mud Input on Organic Matter, $\mathrm{pH}, \mathrm{CaCO} 3$ and Salinity "Case of Wheat"

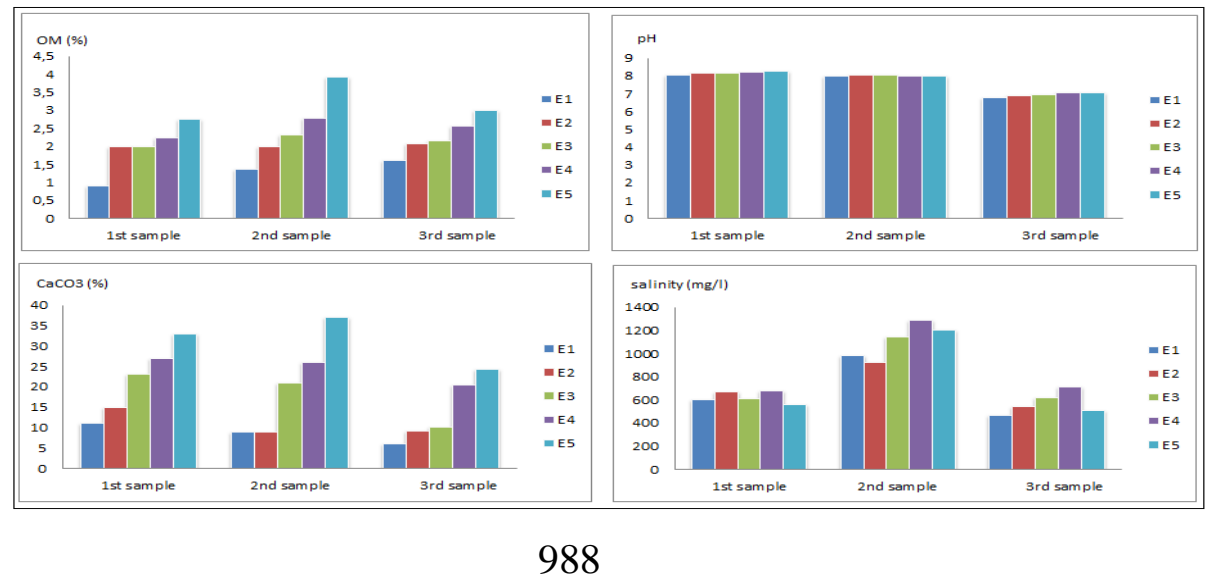


Fig.2 Effects of Mud Inputs on Organic Matter, $\mathrm{pH}, \mathrm{CaCO} 3$ and Salinity in the Case of a Lucerne Crop

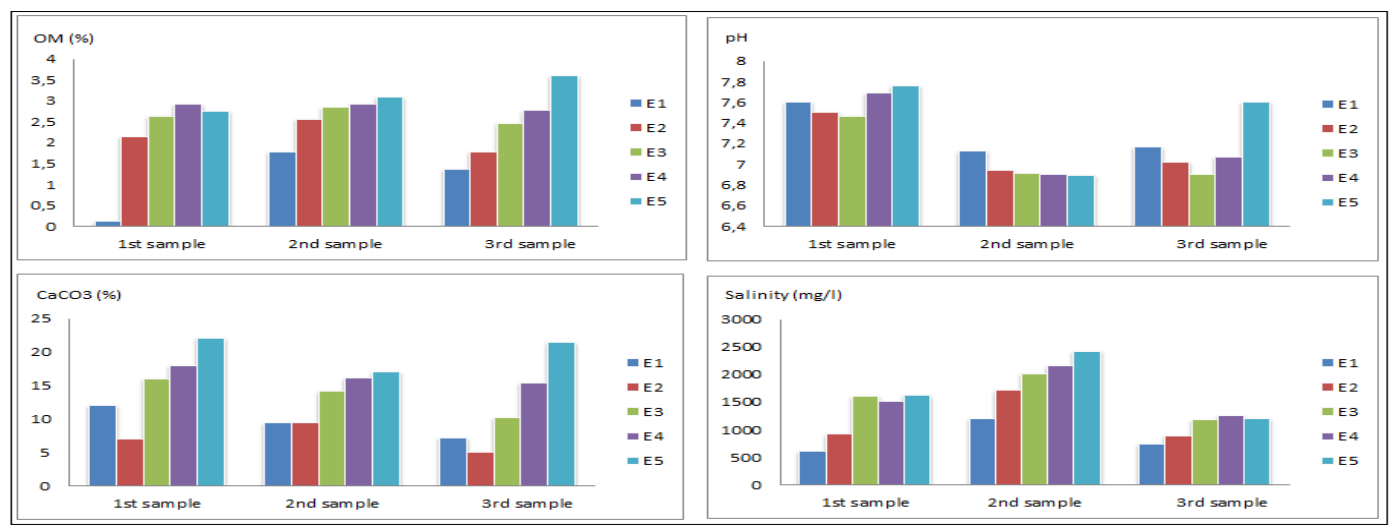

Fig.3 Evolution of Chemical Parameters (M.O, pH...) in the Study Lucerne and Wheat

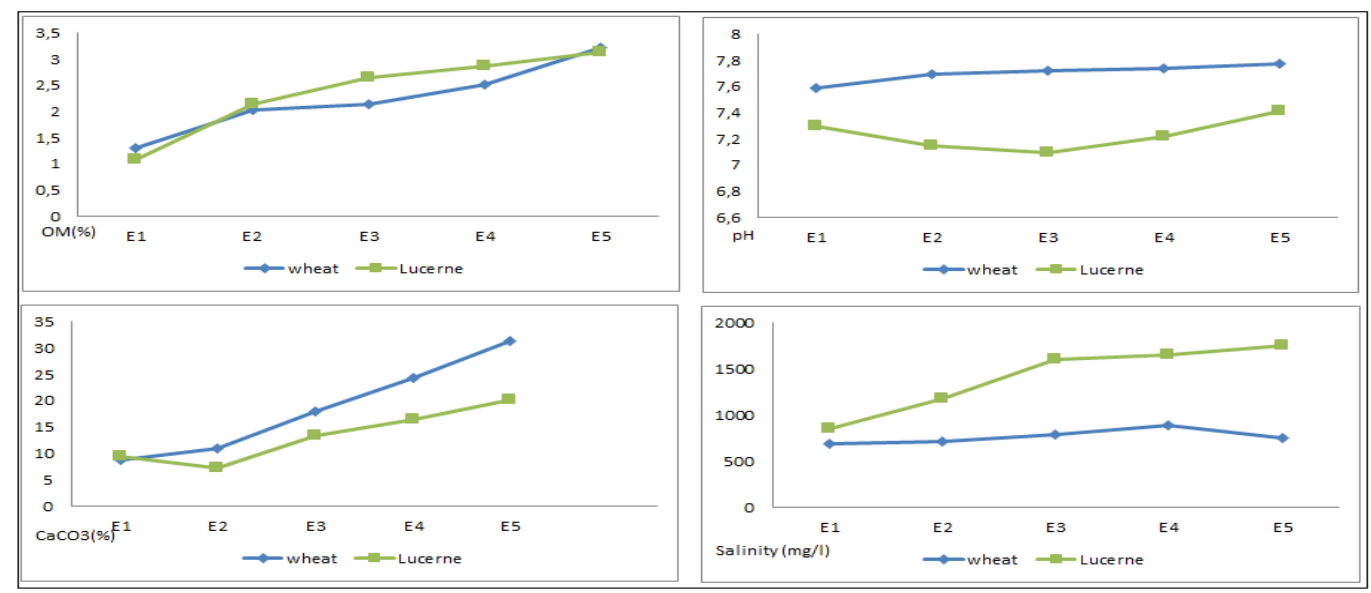

pH

The $\mathrm{pH}$ seems to be responding to the effect of the crop type; the $\mathrm{pH}$ of the uncultivated soil is higher than that of the soil cultivated by Lucerne; something that is not the case for the soil cultivated by wheat where the control soil registers lower values than that of the cultivated soil.

In the record a difference between Lucerne and wheat crop and it's from the E3, E4 and E5 doses that we clearly feel the effect of the type of crop on the chemical properties of the soil.

\section{Calcium Carbonates}

Contrary to the soil cultivated by Lucerne, which records a weaker content of calcium carbonate compared to the control soil, the soil cultivated by wheat records a high rate of $\mathrm{CaCO} 3$ compared to that recorded by the uncultivated soil. The evolution of the rate of $\mathrm{CaCO} 3$ is marked as a functionof the effect of crop type beginning from doses E2, E3, E4 and E5.

\section{Salinity}

The cultivated soil has high salinity values compared to the values of the uncultivated 
soil in the case of a Lucerne crop while the salinity for wheat remains comparable. Thus, the control soil records a very low salinity value compared to the soil cultivated by Lucerne while it records a low salinity value compared to the soil cultivated by wheat. From the $500 \mathrm{~g}$ up to the $200 \mathrm{~g}$ dose, we remark that the values are clearly very high in the case of Lucerne compared to that of wheat.

In conclusion, the effects of beneficiation of sludge sweets on the chemical property of soils through the monitoring of certain indicators (organic matter, $\mathrm{pH}$, calcium carbonates and salinity) enable us to highlight:

Increase level of organic matter on a dosedependent basis. This increase is greater in cultivated soils compared to uncultivated soils.

That change in the rate of organic matter over time has the tendency to reduce; this could be attributed to the phenomenon of mineralization.

That $\mathrm{pH}$ values do not seem to be affected by the addition of sludge; but we see different effects depending on the kind of the two crops.

That calcium carbonates have the tendency to significantly increase when the dosage of mud is also increased.

That the effect of crop type on carbonates is significantly seen within the third dose.

That the salinity of the soils increases with increasing rate of sludge dosage. This increase varies depending on the nature of the crop.
That the soils salinity records a significant decrease over time from the first to the third sample.

Lastly, we can say that, within the limits of the results obtained, the spreading (dosage) of sludge sweet contribute significantly to the change in the chemical property of our studied soil.

\section{References}

Barbartik, A., lawarabnce, J.R., Sikpra, J., and colacicco, D. 1985. Factors affecting the mineralization of nitrogen in sewage sludge applied to soil. Am. J. Soil Sci., 49: 1403-1406.

Benmouffok, A., Allili, N., djebala, L., Akilaandmedjani, A. 2005. Caractérisation et valeur agronomique des boues issues d'épuration des eaux usées (cas de la station d'épuration de Tizi Ouzou Est, Algérie), Watmed2 (Marrakech) $4 \mathrm{p}$.

Brossard, M., Mench, M., Clairon, M., and Laurent, J.Y. 1991. Evolution à court terme de forms de phosphore d'un sol ferralitique après apport d'une boue urbaine. Science des sols, 699$706 \mathrm{p}$.

Chamley, H. 1966. Guide des techniques du laboratoire de Géologie Marine de Luminy, 198 p.

Clapp, C.E., Stark, S.A., Clay, W.E., Larson. 1986. Sewage Sludge organic matter and soil properties. In the role of organic matter in modem agriculture. Chen Y. and avnimelech Y. Eds. - Martinus Nijhoff publ. (Dordrecht) 209-251 p.

Gomez, A., Lineres, A., Tanzin, J., Solda, P. 1984. Etude de l'incidence des apports de boues résiduaires à des sols sableux, sur l'évolution quantitative et qualitative de la 
matière organique. CR. Acad. Sc. Fr., 516-524 p.

Jamil, M., Qacim, M., Umar, M. 2006. Utilization of sewage sludge as organic fertilizer in sustainable agriculture. J. of Appl. Sci., 6(3): 531-535 p.

Juste, C., Catroux, G. 1980. Intérêt agronomique des boues résiduaires et condition préalables à leurs utilisations C.R. séminaire. EAS. Bale, 1-24 p.

Khaleel, R., Reddy, K.R., Overcash, M.R. 1981. Changes in soil physical properties due to organic waste applications: a review. J. Environ. Qual., 10: 133-141 p.

King, L.D., Morris, H.D. 1992. Land disposal of liquid sewage sludge: II. The effect on soil $\mathrm{pH}$, Manganése, Zinc and growth and chemical composition of rye (secale cereales L.). J. Environ. Qual., 1(4): 425-429 p.

Liners, M., Chaussod, R., Juste, C., Solda, P. 1988. Microbial biomass and biological activities in an acid sandy soil treated with sewage sludge or farmyard measure in a long term field experiment. Proc. Conference "Sewage sludge treatment and use; new developments. Technological aspects and environmental effects" Amsterdam.

Liners, M., Juste, C., Tauzin, J., Gomez, A. 1985. Effect of a long term sludge disposal on the soil organic matter characteristics. Proc. 4th Internat
Symposium "Processing and use of organic sludge and liquid agricultural wastes", Rome, Riedel Publ. C. Dordrecht (NLD) 336-347 p.

Marisot, A. 1986. Répercussions agronomiques des épandages d'effluents des industries agricoles et alimentaires. Ann. Agro., 25: 24366.

Mc lead, E.O. 1982. $\mathrm{pH}$ and lime requirements. In: Page, A.L. et al. (Eds.), Methods of Soil Analysis, Part 2, second ed., Agronomy, vol. 9 Soil Society of America, Madison, WI, 199-244.

Pescod, M.B. 1992. Wastewater treatment and use in agriculture. Publication FAO, irrigation et drainage $\mathrm{N}^{\circ} 47$ $117 \mathrm{p}$.

Rapport annuel. COSUMAR. 2009.

Remy, C., Marin-lafleche, A. 1976. L'entretien organique des terres cout d'une politique de l'humus. CETA Entreprises Agricoles, 84: 1-7 p.

Rhoades, J.D. 1982. Methods of Soil Analysis. Madison (USA).

Sommers, L.E. 1977. Chemical composition of sewage sludge and analysis of their potential fertilizers use. $J$. Envir. Qual., 6: 225-232 p.

Walkley, A., Black, I.A. 1934. An examination of the Degtjareff method for determining organic carbon in soils: Effect of variations in digestion conditions and of inorganic soil constituents. Soil Sci., 63: 251-263 p.

\section{How to cite this article:}

Najib Saber, Hajar Mohcine and Imane Benazzouz. 2016. Effect of the Spreading of Sludge on the Chemical Quality of Clay Soil; Casablanca-Morocco. Int.J.Curr.Microbiol.App.Sci. 5(4): 984-991. doi: http://dx.doi.org/10.20546/ijcmas.2016.504.112 